\title{
Therapeutic effects of Vitamin D and IL-22 on methotrexate-induced mucositis in mice
}

\author{
Ebru Yllmaz ${ }^{1}$, Zehra Azizoglu², Kubra Aslan², Serife Erdem², Yesim Haliloglu², Pınar \\ Alisan Suna ${ }^{2}$, Kemal Deniz ${ }^{2}$, Abdulkadir Taşdemir ${ }^{3}$, Sedat Per $^{2}$, Ahmet Eken², Ekrem \\ $\mathrm{Unal}^{2}$, Musa Karakukcu ${ }^{4}$, and Turkan Patıroglu ${ }^{1}$ \\ ${ }^{1}$ Erciyes University \\ ${ }^{2}$ Erciyes University School of Medicine \\ ${ }^{3}$ Kayseri Universitesi \\ ${ }^{4}$ Erciyes Universitesi Tip Fakultesi
}

July 28, 2020

\begin{abstract}
Background: Mucositis is a common side effect of cancer therapies and transplant conditioning regimens. Management of mucositis involves multiple approaches from oral hygiene, anti-inflammatory, anti-apoptotic, cytoprotective and antioxidant agents, to cryo-, physical therapy, and growth factors. There is room for novel, affordable treatment options or improvement of currently available therapies. Vitamin D (Vit D) has been shown to regulate mucosa- resident cell populations such as Th17 or innate lymphoid cells and critical mucosal cytokine IL-22, however their therapeutic potential has not been put to test in preclinical mouse models. In this study, we aimed to test the therapeutic potential of Vit D injections and IL-22 overexpression in a murine model of chemotherapy-induced mucositis. Methods: Balb/c mice were given daily intraperitoneal injections of Vit D. Another group received IL-22 plasmid via hydrodynamic gene delivery. Mucositis was induced by methotrexate. Weight loss, intestinal histopathology and IL-22, IL-17A and GM-CSF protein levels in intestinal tissue were measured. Intestinal Il23, Ifng, Tnfa and Il10 gene expression were analyzed by real-time qPCR. Intestinal lamina propria B cell, neutrophil and total innate lymphoid cells were quantified. Results: Daily Vit D injections significantly ameliorated intestinal inflammation and elevated intestinal IL-22 levels compared with control groups. Temporal overexpression of IL-22 by hydrodynamic gene delivery slightly increased intestinal IL-22 but failed to confer significant protection from mucositis. Conclusion: To our knowledge, this is the first experimental demonstration in animal model of mucositis that Vit D and IL-22 supplementation may be beneficial and warrants further trials in human patients.
\end{abstract}

\section{Introduction}

Mucositis is the painful inflammation and ulceration of oral or gastrointestinal tract and is usually caused by cancer therapies. ${ }^{1}$ Thinning of the oral mucosa, a late side effect of cancer treatment can cause chronic or non-healing ulcers. Gastrointestinal obstruction, necrosis and perforation can also lead to gastrointestinal damage. ${ }^{1,2}$ Side effects of cancer treatment occur more in cells with rapid proliferation and normal tissues containing rapidly growing cell populations of the host can also be damaged. ${ }^{3}$ Chemotherapy and radiotherapy cause DNA damage; they stimulate the formation of free oxygen radicals and can directly affect non-DNA targets. As a result, macrophages are activated and molecules that activate transcription factors, including nuclear factor kappa $\mathrm{B}(\mathrm{NF}-\mathrm{BB})$, are triggered. The production of proinflammatory cytokines such as Tumor necrosis factor alpha (TNF- $\alpha$ ), Interleukin (IL)-6 and IL-1 increase. The mucosa becomes susceptible to bacterial contamination because of tissue damage and ulceration. The mucosal integrity in the epithelial cells is rearranged with the proliferation, differentiation and migration and the recovery phase 
begins. ${ }^{2,4}$ Mucositis may cause significant problems such as abdominal pain, ulceration, dysphagia and diarrhea, decreased fluid and nutrient intake, dehydration and weight loss. These problems require parenteral nutrition of the patient and prolonged hospitalization. Furthermore, they cause speech difficulties, communication disorder, consequently, lowers the quality of life. The prevalence of mucositis is three-fold higher in children than in adults and can lead to serious respiratory disorders. ${ }^{5}$ The development and recovery phase of mucositis vary according to the dose and frequency of the drugs used and the tolerance of the patient. ${ }^{2}$

Vitamin D (Vit D) is a crucial fat-soluble micronutrient that plays key roles in bone and teeth development, protection from cardiovascular diseases, cancer and regulation of immune system. ${ }^{6}$ Vit D induces intestinal stem cell maturation and may suppress colitis by protecting the mucosal epithelial barrier. ${ }^{7,8}$ Data suggest that Vit D levels may impact mucositis severity. In pediatric acute lymphoblastic leukemia patients above the age of 4, Vit D deficiency has been reported. During methotrexate (MTX) therapy, 25(OH)D3 level was low and more severe oral mucositis was observed in these patients. ${ }^{9}$ Importantly, a 59 -year old patient with breast carcinoma treated by docetaxel, trastuzumab and carboplatin who had low Vit D levels initially, has been given Vit D and his chemotherapy-dependent oral mucositis has improved. ${ }^{10}$ Studies show that in Vit $\mathrm{D}$ receptor $(\mathrm{VDR})^{-/-}$mice, levels of IL-1 $\beta$ and TNF- $\alpha$ following induction of colitis were elevated. ${ }^{11,12}$ Thus, these studies suggest that Vit D may be beneficial may limit the severity of chemotherapy-induced mucositis. However, to our knowledge, this has not yet been tested in an animal model of mucositis.

IL-22, is a critical cytokine in modulating tissue responses during inflammation. IL-22 is expressed by many lymphocytes, including T helper (Th) 17, Th22, Natural killer T (NKT) cells, Group 3 Innate Lymphoid Cells (ILC3s) and neutrophils. ${ }^{13}$ IL-22 binds to a heterodimeric receptor composed of IL-22RA1 and IL-10RB subunits which mainly expressed by non-hematopoietic cells, such as epithelial cells of the gastrointestinal tract and skin. ${ }^{14}$ IL-22 is constitutively expressed in the normal colon mucosa, and is critical in barrier immunity, containment of microbiota on the luminal side of the intestine, and intestinal tissue homeostasis. ${ }^{15}$ More importantly, ILC3s cells have been shown to be play a protective role in the murine methotrexateinduced mucositis model via IL-22 mediated mechanisms. ${ }^{16}$ However, to our knowledge, whether recombinant IL-22 or its over expression could be therapeutically exploited to suppress or improve the severity of mucositis has not yet been tested.

In this project, we aimed to test the therapeutic impact of Vit D treatment or IL-22 overexpression on the methotrexate-induced mucositis pathogenesis in Balb/c mice.

\section{Methods}

\subsection{Mice and reagents}

Approval for animal study was obtained from the animal ethics committee of Erciyes University. The Balb/c mice were housed under specific pathogen-free conditions. Six groups of mice were created. These groups were (1) control, (2) Vit D, (3) MTX, (4) IL-22, (5) MTX + Vit D and (6) MTX + IL-22. Vit D was diluted in sunflower oil, thus, sunflower oil was given to controls as vehicle. Daily weight loss was checked and recorded. On Day $4^{\text {th }}$ of MTX treatment, mice were sacrificed. After euthanization, brain, spleen, blood, poop, kidney, liver, esophagus, stomach, $\sim 1 \mathrm{~cm}$ piece from intestine, jejunum, ileum, proximal and distal colon were taken. Mice lymphocytes from lymph nodes and spleen were isolated. The serum of the blood was separated by a centrifugation at $6000 \mathrm{~g}$ for $10 \mathrm{~min}$.

\subsection{Mucositis induction}

Vit D was administered intraperitoneally ( $25 \mathrm{mcg} / \mathrm{kg}$ per mouse). MTX was administered intraperitoneally (120 mg/kg Day -1, $60 \mathrm{mg} / \mathrm{kg}$ Day 0). IL-22 plasmid was administered through hydrodynamic injection at the tail vein in $2 \mathrm{ml}$ saline $(15 \mathrm{mcg} / \mathrm{ml})$ on day -2 .

\subsection{Lymphocyte isolation and staining}

Mice lymphocytes from intestines were isolated as described previously. ${ }^{17,18}$ Pieces of ileum, $3 \mathrm{~cm}$ in length, were cleaned off feces by flushing with a syringe containing $10 \mathrm{ml}$ PBS. Cleaned pieces were cut with a scalpel 
imnto $0.5 \mathrm{~cm}$ pieces. The ileum pieces were predigested with $10 \mathrm{ml}$ Pre-digestion buffer (Phosphate-buffered saline: PBS + Ethylenediaminetetraacetic acid: EDTA) at 37 degrees for 20-30 minutes (shaker incubator). Supernatant were removed. Ileal pieces were transferred into $10 \mathrm{ml}$ Digestion solution (collagenase, DNase, complete RPMI) and the SI tissues were further cut into $1 \mathrm{~mm}$ pieces with a scalpel. Then, SI tissues were incubated at 37 degrees for 45-60 minutes via shaker incubator. After $1 \mathrm{~min}$ of vortexing, the cells were passed through the $70 \mu \mathrm{m}$ cell strainer. The cells were centrifuged ( $400 \mathrm{~g})$ for 5 minutes and the supernatant was discarded. The pellet was resuspended in $5 \mathrm{ml} 40 \%$ percoll and overlayed on $5 \mathrm{ml} 90 \%$ percoll.The percoll gradient was centrifuged for 20 minutes at $400 \mathrm{~g}$ w/o brakes. The lymphocytes at the interphase was collected, counted by trypan blue.

Staining was performed in round bottom 96-well plates. Fc-block was added and incubated for 5 minutes. Then, ILC staining antibodies were added according to manufacturer's dilution recommendation. After 30 minutes of incubation in dark and on ice, cells were washed with staining buffer twice, spun at $400 \mathrm{~g}$. Then, cells were resuspended in $200 \mu \mathrm{l}$ staining buffer and run on FACSAria III. ${ }^{17,18}$ Antibody list: Alexa Fluor 647 Anti-Mouse NK1.1 (clone: PK136), APC Anti-Mouse CD11b (clone: M170), APC Anti-mouse CD3 (clone: 17A2), PE/Cy7 Anti-Mouse CD90 (clone: 30H12), PerCP/Cy5.5 Anti-Mouse CD45 (30F11), FITC Anti-Mouse B220 (RA3-6B2).

\subsection{Enzyme-Linked Immunosorbent Assay (ELISA)}

For intestinal cultures, $1 \mathrm{~cm}$ piece of tissue was cut from the ileum cleaned with PBS containing antibiotics 5 times. The pieces were cultured in a $5 \% \mathrm{CO} 2$ incubator at $3{ }^{\circ} \mathrm{C}$ for 48 hours containing anti-anti. Supernatants were collected for ELISA. Blood from mice was centrifuged and serum was then frozen at $-80^{\circ}$ C. Supernatants were used for mouse IL-22, IL-17A and GM-CSF ELISA. The manufacturer's protocol was followed.

\subsection{Flow Cytometry}

Cells were stimulated with Phorbol 12-Myristate 13-Acetate (PMA), Ionomycin, Golgi Stop (50 ng / ml, $1 \mu \mathrm{g} / \mathrm{ml}, 1 \mu \mathrm{l} / \mathrm{ml}$, respectively) for 4 hours in a 37?C incubator. Cells were fixed for 15 minutes and permeabilized with the BD Cytofix / Cytoperm Plus kit. The single cell suspension was stained with antibodies $30 \mathrm{~min}$ on ice at dark after 5 minutes after blocking with mouse TruStainFcX (BioLegend, San Diego, CA, USA) in staining buffer (2\% FBS in PBS) with appropriate dilution. Data collection was performed on FacsAriaIII. FlowJo or Diva software was used to analyze flow cytometry data.

\subsection{Histology}

The small intestine, kidney and liver tissues were immediately fixed in $10 \%$ buffered formalin solution in normal saline for $24 \mathrm{~h}$, followed by washing with distilled water, dehydration in serial dilutions of alcohol, dehydration in xylene. The samples were embedded in paraffin for $24 \mathrm{~h}$ in a hot-air oven at $56{ }^{\circ} \mathrm{C}$. Paraffinembedded tissues were sectioned as $5 \mu \mathrm{m}$ and stained with hematoxylin and eosin (H\&E). Histological specimens from the small intestine, kidney, and liver tissues were histopathologically evaluated using slides stained with H\&E. The slides were then examined under a light microscope (Olympus BX51, Tokyo, Japan) and photographed. Histopathological scoring was performed semi-quantitatively to assess the tissue injury index in examined sections. The assessment was expressed as the sum of the individual score grades (0: no findings, 1: mild, 2: moderate, or 3: severe) for each of the following parameters: degeneration, cellular swelling, cellular vacuolization, necrosis, congestion, and hemorrhage.

\subsection{Statistical analysis}

GraphPad Prism 6 software was used for statistical analyses. Two tailed, Unpaired Student's t test and one-way ANOVA with Dunnett's post-test analysis were used for significance analyses. $\mathrm{P}$ value $<=0.05$ is accepted as statistically significant.

\section{Results}

\subsection{IL-22 overexpression or Vit D supplementation does not protect mice from weight loss}


In this project, mucositis was induced by intraperitoneal injections of methotrexate on days -1 and 0 . IL22 overexpression group received IL-22 plasmids via hydrodynamic gene delivery on day -2 as previously described. ${ }^{15}$ In our previous studies such injections were shown to result in durable systemic IL-22 expression compared with costly recombinant protein injections. ${ }^{19}$ Vit D injection was initiated on day -5 and mice received daily injections until termination of the experiment. To assess the impact of Vit D injections and IL-22 overexpression weight loss was recorded daily (Fig 1). Either treatment did not affect wasting disease post methotrexate administration suggesting that these treatments may not have impacted circulatory factors contributing to weight loss.

\subsection{Vit D improves Histopathological Scores of Mucositis}

Light microscopic examination of the parts of the small intestine in the control mice showed normal morphology with villi, long crypts, intact lining epithelium with normal mucus-secreting cells, and normal cellularity lamina propria (Fig 2A). The administration of IL-22 alone caused a slight alteration in mucosal morphology in the small intestine. The tips of the villi were mildly blunted but the crypts were generally normal. As is seen from Figure 2A, normal mucosa and structures are monitored on the full-thickness histopathological sections of the intestine tissue of the Vit-D-treated mice. Histological studies showed that MTX treatmentinduced serious damage to the intestine (Fig 2). The results revealed that MTX-induced small intestinal injury was characterized by villous shortening, leukocyte infiltration, crypt abscess, and crypt epithelial damage in the mucosa (Fig 2A). Mild villus superficial epithelial damage, leukocyte infiltration, and protected crypt structures are seen in the intestinal tissue of the MTX+IL-22 group. Clear improvement in the intestine was noticed when the mice were treated with MTX and the Vit-D. The histopathological findings of our study revealed that Vit D ameliorated mucosal destruction and preserved the intestinal epithelium morphology, but even mild pathological changes continue such as crypt abscess.

\subsection{Vit D treatment augments IL-22 production in the intestine}

Studies in mice showed that intestinal ILC3s development and IL-22 production are regulated by Vit D, and its receptor (VDR) signaling. On one hand, Vit D or VDR deficiency thus reduced intestinal ILC3s and IL-22. ${ }^{11,12}$ On the other hand, exposure of human ILC3s to Vit D was shown to reduce IL-23R expression and IL-22 production. ${ }^{20}$ Given the regenerative roles of IL-22 on intestinal epithelia, we assessed the impact of intraperitoneal Vit D or IL-22 overexpression on intestinal tissue IL-22 levels along with other Th17-signature cytokines (Fig 3). Intestinal tissue cultures showed elevated IL-22 production in both Vit D treated and IL22 overexpressed mice groups compared with control group. The increase in Vit D group was more profound compared with IL-22 overexpression group. IL-17A or GM-CSF cytokines were not statistically significant across the mice groups.

Levels of IL-23, IFN- $\gamma$, TNF- $\alpha$ and IL-10 was measured by real-time qPCR in intestinal biopsies obtained at the end of the experiment (Fig 4). Although IL-23 was elevated post methotrexate, none of the cytokines were statistically different across the groups. Finally, we quantified the numbers of B cells, neutrophils and total ILC in the lamina propria of all mice groups on $5^{\text {th }}$ day of mucositis (Fig 5, Supp Fig 1 and 2). Neutrophils appeared to increase in number after methotrexate treatment, however, across all animal groups, numbers were comparable (Fig 5).

\section{Discussion}

Although Vit D deficiency has been shown to correlate with poor prognosis in cancer therapy-induced mucositis, no animal model study experimentally tested whether Vit D supplementation could have therapeutic effects on mucositis course. IL-22 is a critical cytokine for gastrointestinal homeostasis and restoration of damaged intestinal/mucosal tissues. Absence of IL-22 exacerbates mucositis outcome in the murine models and Vit D-mediated signaling was shown to regulates IL-22 production in both mice and humans. However, whether recombinant IL-22 or its genetic overexpression would have therapeutic benefit has not yet been put to test neither in animal models, nor in humans. In this study, our data revealed that in a preclinical model of methotrexate-induced mucositis, Vit D supplementation could improve mucositis, and the protection may be IL-22 mediated. 
Our data revealed that Vit D injections ameliorated mucositis pathology. Injections were initiated 4 days prior to methotrexate injection in order to give Vit D time to have its effects on mucosal cells, thus, it was considered for prophylaxis. These results are consistent with previous findings that Vit D deficiency is associated with more severe mucositis both in adults and pediatrics. ${ }^{9}{ }^{21}$ Nejatinamini et al. reported that lower intake of vitamins and plasma 25-hydroxy Vit D (25-OHD) was associated with mucositis in head and neck cancers treatments. ${ }^{21}$ The patients included both radiation and chemotherapy or combined therapy groups ( $22 \%$ radiotherapy, $71 \%$ chemotherapy, $7 \%$ both). Similar observations were made in acute lymphoblastic leukemia in children. ${ }^{9}$ Safety of Vit D supplementation in pediatric cases prior to hematopoietic cell transplantation have also been reported. ${ }^{22}$ Data from a study by Anand et al. ${ }^{23}$ with adult oral cancer patients revealed that Vit D supplementation significantly improved treatment associated mucositis. Another study with smaller patient cohort size $(n=14)$ found no significant benefit. ${ }^{24}$ Therefore collectively, these data argue for a beneficial role for Vit D in improving treatment-associated mucositis in cancers and perhaps hematopoietic stem cell transplantation. ${ }^{25}$

IL-22 is an important cytokine in gut homeostasis. Intestinal epithelial cells express IL-22 receptors and IL-22R signaling in these cells promotes regeneration of epithelial tissue. Indeed, its absence renders mice susceptible to dextran sulfate sodium (DSS)-induced models of colitis. ${ }^{26}$ This also is valid for CD4+ naïve $\mathrm{T}$ cell induced models of colitis. ${ }^{19,26,27}$ In addition to intestinal tissue remodeling IL-22 signaling stimulates production of mucus, anti-microbial peptides which are crucial for epithelial barrier immunity and homeostasis. ${ }^{28}$ In the intestinal lamina propria or other mucosal tissues, IL-22 is produced by Th17 cells, ILC3s, mucosal-associated invariant T (MAIT) and gamma delta T cells. Vit D and VDR signaling was shown to be critical for development and function of ILC3s and forkhead box P3 (FOXP3) ${ }^{+}$Treg cells in gastrointestinal system. ${ }^{11,12}$ Thus, diminished number of ILC3s and subsequently reduced levels of IL-22 and IL-10 was reported in the deficiency of Vit D. ${ }^{11,}{ }^{12}$ Our cytokine data of IL-22 levels are in line with these reports. Vit D treatment augmented intestinal IL-22 production. IL-22 hydrodynamic delivery also increased IL-22 levels. The effect of Vit D IL-22 was more profound than hydrodynamic delivery group. This was also reflected in the histopathology scores. In our model, Vit D did not appear have an impact on total ILC levels. This might be due to relatively short treatment time.

In summary, our results show that Vit D treatment may provide partial protection from chemically-induced mucositis in mice.

\section{Conflicts of interest}

The authors declare no conflict of interest.

\section{Credit authorship contribution statement}

Ebru Yilmaz : Performed experiments, collected data, revised, and edited the manuscript. Zehra Busra Azizoglu: Performed experiments, collected data, wrote, revised, and edited the manuscript.Kubra Aslan : Performed experiments, collected data, wrote, revised, and edited the manuscript. Serife Erdem : Performed experiments, collected data, edited the manuscript. Yesim Haliloglu : Performed experiments, collected data, edited the manuscript, Pinar Alisan Suna : Performed experiments, collected data, interpreted, wrote, and edited the manuscript. Kemal Deniz : Performed experiments and edited the manuscript.Abdulkadir Tasdemir : Performed experiments and edited the manuscript. Sedat Per : Performed experiments, and edited the manuscript, conceptualized, and designed the study provided funding.Ahmet Eken : Performed experiments, collected interpreted data, wrote, revised, and edited the manuscript, supervised, conceptualized, and designed the study and provided resources. Ekrem Unal : Conceptualized, designed, and supervised the study, provided funding, interpreted data, revised, and edited the manuscript. Musa Karakukcu : Provided funding and edited the manuscript, andTurkan Patiroglu : Provided funding and edited the manuscript.

\section{References}

1. Cinausero M, Aprile G, Ermacora P, Basile D, Vitale MG, Fanotto V, Parisi G, Calvetti L, Sonis ST. 
New frontiers in the pathobiology and treatment of cancer regimen-related mucosal injury. Front Pharmacol , 2017 8: 354.

2. Sonis ST. The pathobiology of mucositis. Nat Rev Cancer , 2004 4: 277-284.

3. Pico J, Avila-Garavito A, Naccache P. Mucositis: Its Occurrence, Consequences, and Treatment in the Oncology Setting. Oncologist, 1998 3: 446-451.

4. Sonis ST, Elting LS, Keefe D, Peterson DE, Schubert M, Hauer-Jensen M, Bekele BN, Raber-Durlacher J, Donnelly JP, Rubenstein EB. Perspectives on cancer therapy-induced mucosal injury. Cancer , 2004 100: 1995-2025.

5. Avritscher EBC, Cooksley CD, Elting LS. Scope and epidemiology of cancer therapy-induced oral and gastrointestinal mucositis. Semin Oncol Nurs, 2004 20: 3-10.

6. Pludowski P, Holick MF, Pilz S, Wagner CL, Hollis BW, Grant WB, Shoenfeld Y, Lerchbaum E, Llewellyn DJ, Kienreich K, Soni M. Vitamin D effects on musculoskeletal health, immunity, autoimmunity, cardiovascular disease, cancer, fertility, pregnancy, dementia and mortality-A review of recent evidence. Autoimmun Rev , 2013 12: 976-989.

7. Peregrina K, Houston M, Daroqui C, Dhima E, Sellers RS, Augenlicht LH. Vitamin D is a determinant of mouse intestinal Lgr5 stem cell functions. Carcinogenesis, 2015 36: 25-31.

8. Liu W, Chen Y, Golan MA, Annunziata ML, Du J, Dougherty U, Kong J, Musch M, Huang Y, Pekow J, Zheng C, Bissonnette M, Hanauer SB, Li YC. Intestinal epithelial vitamin D receptor signaling inhibits experimental colitis. J Clin Invest, 2013 123: 3983-3996.

9. Oosterom N, Dirks NF, Heil SG, de Jonge R, Tissing WJE, Pieters R, van den Heuvel-Eibrink MM, Heijboer AC, Pluijm SMF. A decrease in vitamin D levels is associated with methotrexate-induced oral mucositis in children with acute lymphoblastic leukemia. Support Care Cancer , 2019 27: 183-190.

10. Fink M. Vitamin D Deficiency Is a Cofactor of Chemotherapy-Induced Mucocutaneous Toxicity and Dysgeusia [Internet]. J Clin Oncol , 2011 29: e81-e82. [cited 2020 May 8] Available from: http://ascopubs.org/doi/10.1200/JCO.2010.31.5317

11. Lin YD, Arora J, Diehl K, Bora SA, Cantorna MT. Vitamin D is required for ILC3 derived IL-22 and protection from Citrobacter rodentium infection. Front Immunol , 201910.

12. He L, Zhou M, Li YC. Vitamin D/Vitamin D Receptor Signaling Is Required for Normal Development and Function of Group 3 Innate Lymphoid Cells in the Gut. iScience, 2019 17: 119-131.

13. Zenewicz LA. IL-22: There Is a Gap in Our Knowledge. ImmunoHorizons , 2018 2: 198-207.

14. Zhang X, Liu S, Wang Y, Hu H, Li L, Wu Y, Cao D, Cai Y, Zhang J, Zhang X. Interleukin-22 regulates the homeostasis of the intestinal epithelium during inflammation. Int J Mol Med , 2019 43: 1657-1668.

15. Eken A, Singh AK, Oukka M. Interleukin 23 in Crohn's disease. Inflamm Bowel Dis , 2014 20: 587-595.

16. Aparicio-Domingo P, Romera-Hernandez M, Karrich JJ, Cornelissen F, Papazian N, LindenberghKortleve DJ, Butler JA, Boon L, Coles MC, Samsom JN, Cupedo T. Type 3 innate lymphoid cells maintain intestinal epithelial stem cells after tissue damage. J Exp Med , 2015 212: 1783-1791.

17. Eken A. IL-15 negatively regulates curdlan-induced IL-23 production by human monocyte-derived dendritic cells and subsequent Th17 response. North Clin Istanbul , 2019.

18. Eken A, Yetkin MF, Vural A, Okus FZ, Erdem S, Azizoglu ZB, Haliloglu Y, Cakir M, Turkoglu EM, Kilic O, Kara I, Altuntaş HD, Oukka M, Kutuk MS, Mirza M, Canatan H. Fingolimod alters tissue distribution and cytokine production of human and murine innate lymphoid cells. Front Immunol , 201910. 
19. Eken A, Singh AK, Treuting PM, Oukka M. IL-23R+ innate lymphoid cells induce colitis via interleukin22-dependent mechanism. Mucosal Immunol , 2014 7: 143-154.

20. Konya V, Czarnewski P, Forkel M, Rao A, Kokkinou E, Villablanca EJ, Almer S, Lindforss U, Friberg D, Höög C, Bergman P, Mjösberg J. Vitamin D downregulates the IL-23 receptor pathway in human mucosal group 3 innate lymphoid cells. J Allergy Clin Immunol , 2018 141: 279-292.

21. Nejatinamini S, Debenham BJ, Clugston RD, Mawani A, Parliament M, Wismer W V., Mazurak VC. Poor vitamin status is associated with skeletal muscle loss and mucositis in head and neck cancer patients. Nutrients , 201810.

22. Wallace G, Jodele S, Myers KC, Dandoy CE, El-Bietar J, Nelson A, Teusink-Cross A, Khandelwal P, Taggart C, Gordon CM, Davies SM, Howell JC. Single Ultra-High-Dose Cholecalciferol to Prevent Vitamin D Deficiency in Pediatric Hematopoietic Stem Cell Transplantation. Biol Blood Marrow Transplant, 2018 24: $1856-1860$.

23. Anand A, Singh S, Sonkar AA, Husain N, Singh KR, Singh S, Kushwaha JK. Expression of Vitamin D receptor and Vitamin D status in patients with oral neoplasms and effect of Vitamin D supplementation on quality of life in advanced cancer treatment. Wspolczesna Onkol , 2017 21: 145-151.

24. Hamidieh AA, Sherafatmand M, Mansouri A, Hadjibabaie M, Ashouri A, Jahangard-Rafsanjani Z, Gholami K, Javadi MR, Ghavamzadeh A, Radfar M. Calcitriol for oral mucositis prevention in patients with fanconi anemia undergoing hematopoietic sct: A double-blind, randomized, placebo-controlled trial. Am J Ther , 2016 23: e1700-e1708.

25. Raoufinejad K, Shamshiri AR, Pezeshki S, Chahardouli B, Hadjibabaie M, Jahangard-Rafsanjani Z, Gholami K, Rajabi M, Vaezi M. Oral calcitriol in hematopoietic recovery and survival after autologous stem cell transplantation: a randomized clinical trial. DARU, J Pharm Sci , 2019 27: 709-720.

26. Zenewicz LA, Yancopoulos GD, Valenzuela DM, Murphy AJ, Stevens S, Flavell RA. Innate and Adaptive Interleukin-22 Protects Mice from Inflammatory Bowel Disease. Immunity , 2008 29: 947-957.

27. Qiu J, Guo X, Chen Z ming E, He L, Sonnenberg GF, Artis D, Fu YX, Zhou L. Group 3 innate lymphoid cells inhibit T-cell-mediated intestinal inflammation through aryl hydrocarbon receptor signaling and regulation of microflora. Immunity , 2013 39: 386-399.

28. Vaishnava S, Yamamoto M, Severson KM, Ruhn KA, Yu X, Koren O, Ley R, Wakeland EK, Hooper L $\mathrm{V}$. The antibacterial lectin RegIII $\gamma$ promotes the spatial segregation of microbiota and host in the intestine. Science (80- ), 2011 334: 255-258.

\section{Figure Legends}

Figure 1. Experimental Setup and Weight Loss Graph. A)Experimental groups and the daily treatment were shown in the table.B) Weight loss is shown as \% loss compared to initial weight. ( $\mathrm{n}=5-8$ mice per group).

Figure 2. Vit D improves mucositis pathology. A)Representative histology pictures from small intestine of each experimental group. B) Histological scores were charted. ${ }^{*}$ indicates $\mathrm{p}<0.05$. ( $\mathrm{n}=5-8$ mice per group).

Figure 3. Vit D augments intestinal IL-22. ELISA results for ex-vivo ileal tissue culture supernatants (24 h culture). ${ }^{*}$ indicates $\mathrm{p}<0.05 ; * *$ indicates $\mathrm{p}<0.01,(\mathrm{n}=5-8$ mice per group).

Figure 4. Expression of proinflammatory genes during mucositis in the intestinal tissue upon Vit D treatment and IL-22 overexpression. Relative gene expression of il23p19, Ifng, Tnfa and Il10 .

Figure 5. Lymphocyte subsets in the intestine lamina propria during mucositis

Supp Figure 1. Gating strategy for B cells and Neutrophils 
Supp Figure 2. Gating strategy for innate lymphoid cells (ILCs)

Figure $1 \mathrm{~A}$

\begin{tabular}{|c|c|c|c|c|c|c|c|c|c|c|}
\hline & Day -5 & Day -4 & Day -3 & Day -2 & Day -1 & Day 0 & Day +1 & Day +2 & Day +3 & Day +4 \\
\hline Control & $\begin{array}{l}\text { Sunflower } \\
\text { oil }\end{array}$ & $\begin{array}{l}\text { Sunflower } \\
\text { oil }\end{array}$ & $\begin{array}{l}\text { Sunflower } \\
\text { oil }\end{array}$ & $\begin{array}{l}\text { Sunflower } \\
\text { oil }\end{array}$ & Sunflower oil & $\begin{array}{l}\text { Sunflower } \\
\text { oil }\end{array}$ & $\begin{array}{l}\text { Sunflower } \\
\text { oil }\end{array}$ & $\begin{array}{l}\text { Sunflower } \\
\text { oil }\end{array}$ & $\begin{array}{l}\text { Sunflower } \\
\text { oil }\end{array}$ & \multirow{6}{*}{ Sacrificed } \\
\hline MTX & $\begin{array}{l}\text { Sunflower } \\
\text { oil }\end{array}$ & $\begin{array}{l}\text { Sunflower } \\
\text { oil }\end{array}$ & $\begin{array}{l}\text { Sunflower } \\
\text { oil }\end{array}$ & $\begin{array}{l}\text { Sunflower } \\
\text { oil }\end{array}$ & MTX $120 \mathrm{mg} / \mathrm{kg}$ & $\begin{array}{l}\text { Mtx } 60 \\
\mathrm{mg} / \mathrm{kg}\end{array}$ & $\begin{array}{l}\text { Sunflower } \\
\text { oil }\end{array}$ & $\begin{array}{l}\text { Sunflower } \\
\text { oil }\end{array}$ & $\begin{array}{l}\text { Sunflower } \\
\text { oil }\end{array}$ & \\
\hline $\begin{array}{l}\text { Vit-D } \\
(25 \mathrm{mcg} / \\
\mathrm{kg})\end{array}$ & VitD IP & VitD IP & VitD IP & VitD IP & VitD IP & VitD IP & VitD IP & VitD IP & VitD IP & \\
\hline IL-22 & $\begin{array}{l}\begin{array}{l}\text { Sunflower } \\
\text { oil }\end{array} \\
\end{array}$ & $\begin{array}{l}\text { Sunflower } \\
\text { oil }\end{array}$ & $\begin{array}{l}\begin{array}{l}\text { Sunflower } \\
\text { oil }\end{array} \\
\end{array}$ & IL-22 & Sunflower oil & $\begin{array}{l}\begin{array}{l}\text { Sunflower } \\
\text { oil }\end{array} \\
\end{array}$ & $\begin{array}{l}\begin{array}{l}\text { Sunflower } \\
\text { oil }\end{array} \\
\end{array}$ & $\begin{array}{l}\begin{array}{l}\text { Sunflower } \\
\text { oil }\end{array} \\
\end{array}$ & $\begin{array}{l}\text { Sunflower } \\
\text { oil }\end{array}$ & \\
\hline $\begin{array}{l}\text { MTX + } \\
\text { Vit D }\end{array}$ & VitD & VitD IP & VitD IP & VitD IP & $\begin{array}{l}\text { VitD IP } \\
\text { MTX } 120 \mathrm{mg} / \mathrm{kg}\end{array}$ & $\begin{array}{l}\text { VitD IP } \\
\text { Mtx } 60 \\
\mathrm{mg} / \mathrm{kg}\end{array}$ & VitD IP & VitD IP & VitD IP & \\
\hline $\begin{array}{l}\text { MTX + } \\
\mathrm{IL}^{2}-22\end{array}$ & $\begin{array}{l}\text { Sunflower } \\
\text { oil }\end{array}$ & $\begin{array}{l}\text { Sunflower } \\
\text { oil }\end{array}$ & $\begin{array}{l}\text { Sunflower } \\
\text { oil }\end{array}$ & IL-22 & MTX $120 \mathrm{mg} / \mathrm{kg}$ & $\begin{array}{l}\text { Mtx } 60 \\
\mathrm{mg} / \mathrm{kg}\end{array}$ & $\begin{array}{l}\begin{array}{l}\text { Sunflower } \\
\text { oil }\end{array} \\
\end{array}$ & $\begin{array}{l}\text { Sunflower } \\
\text { oil }\end{array}$ & $\begin{array}{l}\text { Sunflower } \\
\text { oil }\end{array}$ & \\
\hline
\end{tabular}

B

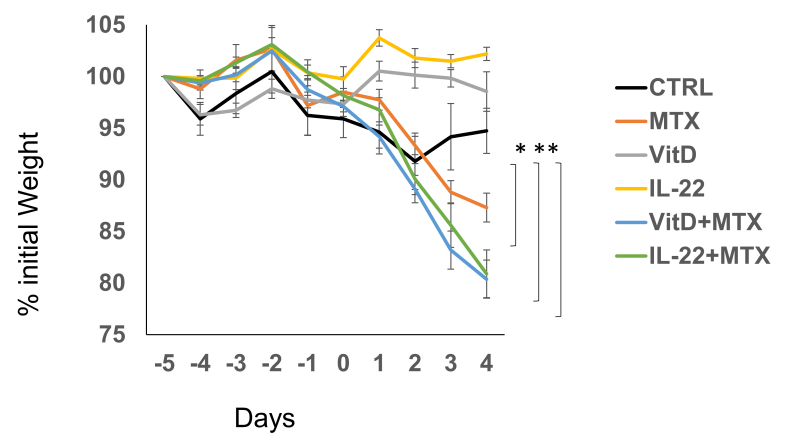

Figure 2A
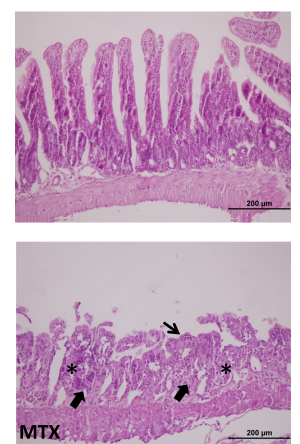

*

* leukocyte infiltration $\rightarrow$ villi

crypt abscess

\section{Figure 3}

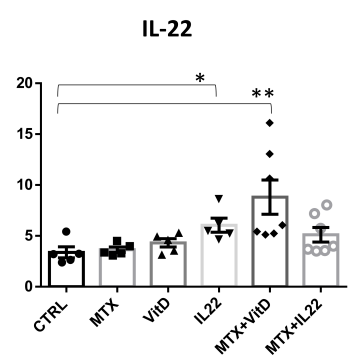

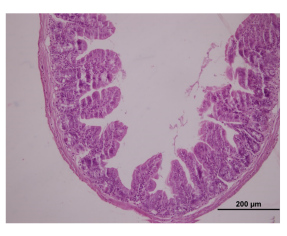

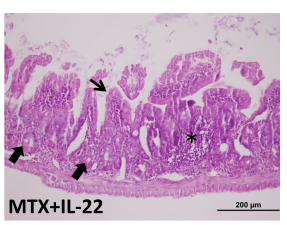

$H \& E$ x20

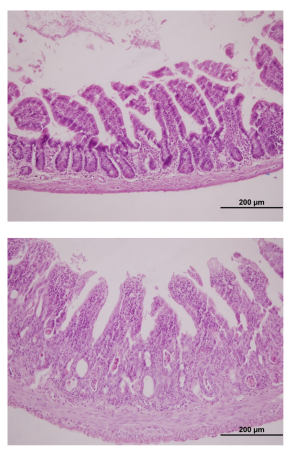

B

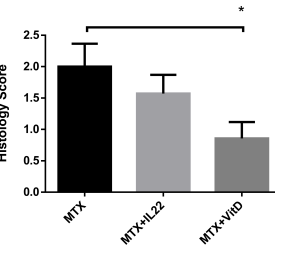


Figure 4
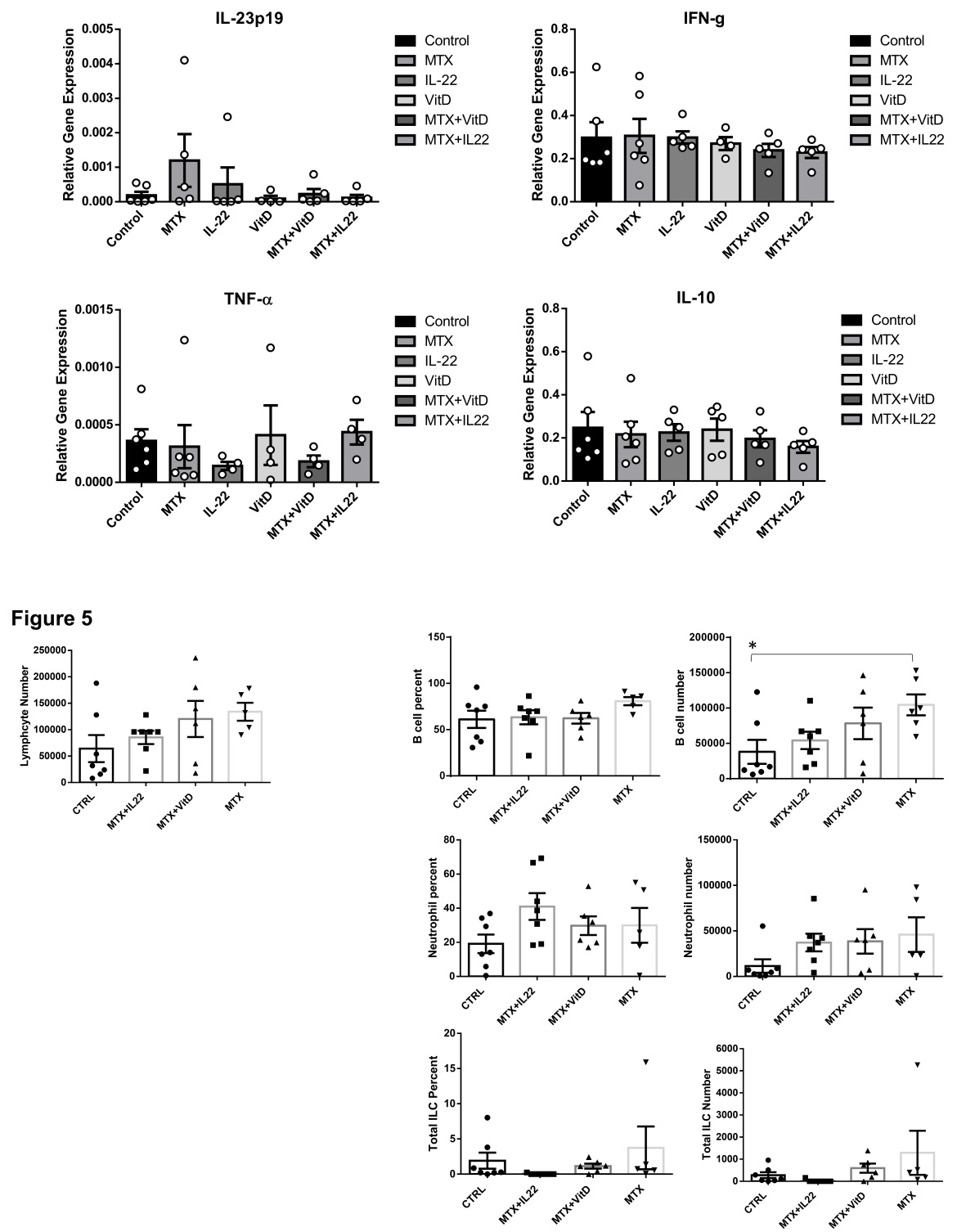